Anderson, Clifford; Wall, Steve

Design of Erosion Protection at Landfill Areas with Slopes Less than $10 \%$

Verfügbar unter / Available at:

https://hdl.handle.net/20.500.11970/100228

Vorgeschlagene Zitierweise / Suggested citation:

Anderson, Clifford; Wall, Steve (2010): Design of Erosion Protection at Landfill Areas with Slopes Less than 10\%. In: Burns, Susan E.; Bhatia, Shobha K.; Avila, Catherine M. C.; Hunt, Beatrice E. (Hg.):

Proceedings 5th International Conference on Scour and Erosion (ICSE-5), November 7-10, 2010, San Francisco, USA. Reston, Va.: American Society of Civil Engineers. S. 1054-1063. 


\title{
Design of Erosion Protection at Landfill Areas with Slopes Less than 10\%
}

\author{
Clifford Anderson ${ }^{1}$, M. ASCE, PE, PhD, D.WRE and Steve Wall ${ }^{2}$
}

${ }^{1}$ Department of Engineering, Central Connecticut State University, 1615 Stanley Street, New Britain, CT 06050-4010, USA, email: cliff@ahymo.com

${ }^{2}$ Office of Pollution Prevention and Solid Waste (WST-7), US EPA Region 9, 75 Hawthorne St., San Francisco, CA 94105, USA, email: Wall.Steve@epamail.epa.gov

\begin{abstract}
Surface water can enter landfill waste zones from top surface areas and erosion of the top surface can cause wash-out of waste material. Landfill covers at these locations must prevent surface water infiltration and provide erosion resistance. In arid climates a rock veneer can be used to reduce erosion, but this will increase infiltration and reduce surface evaporation making it more likely that surface water will enter waste zones. An alternative is the placement of a mix of soil and gravel as a surface layer; the mix is commonly called a gravel admixture. Studies of gravel admixture layers have shown they provide greatly reduced surface infiltration rates over gravel alone, and have evaporation rates very similar to soil alone. A method is presented to compute the rock and soil gradations, and thicknesses of gravel admixture layers based on peak flow, slope and the formation of surface channelization. The procedure is used to select gradation ranges and applicable slope lengths for a landfill cover.
\end{abstract}

\section{INTRODUCTION}

Regulations for closure of municipal waste landfills typically follow the Federal regulations established by the Resource Conservation and Recovery Act (RCRA, 1976, Subtitle D program, 40 CFR 258). These regulations require the top soil layer to have a slope not less than $0.03 \mathrm{~m} / \mathrm{m}$, and not greater than $0.05 \mathrm{~m} / \mathrm{m}$. This minimum slope is required to prevent surface ponding because a landfill is subject to substantial local settlement due to solid waste decomposition. To minimize ponding and infiltration, designers commonly consider slopes approaching the $0.05 \mathrm{~m} / \mathrm{m} \mathrm{limit}$. Steeper slopes of 0.08 or $0.10 \mathrm{~m} / \mathrm{m}$ have been considered for some sites.

In some climate zones a vegetative cover can be used to provide an effective erosion blanket at a landfill cover system. However, in many of the arid and semi-arid areas of the southwest United States, the natural vegetation will cover only 10 to 20 percent of the surface (Anderson and Stormont, 2005). If native plants are used for southwestern landfill cover systems, a continuous erosion blanket is not likely to be created. The impact from raindrops initiates local soil movement, but it is the conveyances across slopes that cause local soil movement to become erosion. The creation of longer or steeper cover slopes can have consequences for erosion that will become obvious only after severe rainfall events.

In dry climates, a gravel surface mulch or veneer can be designed to provide erosion protection. A gravel veneer is typically constructed by placing a 3 to $10 \mathrm{~cm}$ thick layer on the soil surface. The gravel must be of sufficient size that it will not be substantially displaced during a major storm event. Rounded gravel with a diameter of 
1.3 to $5 \mathrm{~cm}(1 / 2$ to $2 \mathrm{in}$.) is typically used. Experimental studies have shown that gravel mulch can significantly reduce sediment yield from a cover (Finley et al., 1985; Wischmeier and Smith, 1978). However, there are two properties of a gravel veneer that discourage landfill use: 1) it can reduce the evaporation rate, and 2) it may create a habitat for deep-rooted plants (Waugh and Petersen, 1994; Kemper et al., 1994).

Some landfills in arid climates are being constructed with thicker soil layers in place of clay or geomenbrane layers because they can provide equivalent or superior performance at a lower cost. The successful function of soil-only landfill covers is very dependent upon the ability of the surface layer to reduce surface infiltration and allow evaporation to remove moisture from the soil cover layers. Waugh and Petersen (1994) suggest that moderate amounts of gravel mixed into the cover topsoil will control both water and wind erosion without the negative effect on vegetation and soil-water balance caused by a gravel veneer. When a mix of soil and gravel is used as a surface layer, the mix is commonly called a gravel admixture. If the gravel admixture contains a sufficient quantity of appropriately sized rock, a gravel admixture will also provide erosion protection in a manner similar to placement of rock alone. The procedures described in this document can be used to guide the design of a gravel admixture that will provide for reduced surface erosion, and create a surface with water infiltration and evaporation similar to a natural soil.

The analyses presented in this document generally apply to landfill top surface areas with slopes between $3 \%$ and $10 \%$. Flatter sloped areas may have settlement and ponding conditions that may not be adequately addressed by ordinary soil covers. The computed admixture layer thicknesses may become large for slopes steeper than $10 \%$ when slope lengths and runoff quantities also become large. While there is nothing in the procedure that specifically limits the use of gravel admixtures to slopes less than $10 \%$, construction economics may lead to other surface treatment methods.

The design of a gravel admixture layer to protect a landfill surface requires evaluation of small watershed hydrology and hydraulics, and the design of the conveyances where water is expected to flow. In the case of most uniformly graded landfill surfaces, a fixed flow path or channel may not be constructed into the surface. The site physical conditions and measurements completed after events at similar areas can be used to predict surface flow conditions. For a landfill top surface in the arid and semi-arid areas of the southwest United States a 100-year event is a suggested design condition, but other site conditions may warrant use of different frequencies.

\section{PEAK FLOW AND UNIT DISCHARGE}

For any given watershed, the 100-year frequency event peak flow $\left(Q_{100}\right)$ can be determined from a basic hydrologic analysis, such as with the Rational Method or NRCS Curve Number $(C N)$ procedure. Peak flow during the storm event is the most important hydrologic property to accurately predict. For a planar watershed surface with an identified length, but a width that can be identified only after erosion has occurred, the recommended watershed width for runoff computations should be $25 \%$ of the watershed length. The dominant discharge peak flow $\left(Q_{m}\right)$ can be evaluated by considering the statistically weighted average of the peak runoff occurring over a long period, for example 100 years. In the arid southwestern the $Q_{m}$ can be estimated at $10 \%$ of $Q_{100}$. For a wide channel section where: 
$\frac{A}{W P}=\frac{b d_{h}}{b+\left(2 d_{h}\right)}=d_{h} \quad$ at $\quad b \gg d_{h}$

Manning's equation for open channel flow can be written to solve for the width of flow (b) as:

$b=Q_{100} n s^{-0.5} d_{h}^{-1.667}$

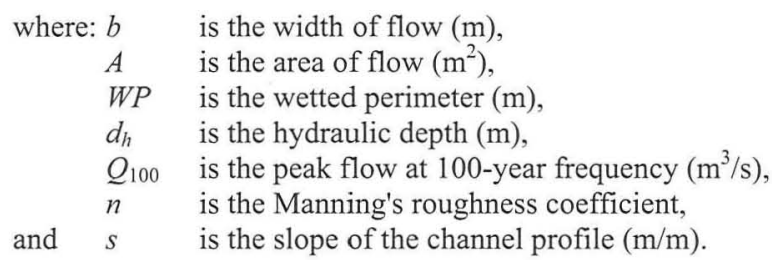

A geomorphologic equation to describe the width of open channel flow as a function of dominant discharge and percentage of silt and clay is given in Engineering Analysis of Fluvial Systems (Simons, Li and Associates, 1982, p 5.47) and in Watershed and Stream Mechanics (D. B. Simons, R. M. Li, et al., 1980, p. 4-37). While this equation was not specifically adapted to address landfill cover runoff, it has been found to provide appropriate values for this application. The geomorphologic equation (converted from US customary to metric form) is:

$b=43.7 Q_{m}^{0.38} M^{-0.34}$

where: $Q_{m} \quad$ is the dominant discharge $\left(\mathrm{m}^{3} / \mathrm{s}\right)$,

and $M \quad$ is the percentage of silt and clay in the channel perimeter.

The value of $Q_{m}$ can be computed as:

$Q_{m}=Q_{100} / D D_{\text {factor }}$

where: $D D_{\text {factor }}$ is the dominant discharge factor $=Q_{100} / Q_{m}$ (Use a value of 10$)$, and $Q_{100}$ is the peak flow at 100 -year frequency $\left(\mathrm{m}^{3} / \mathrm{s}\right)$.

Manning's equation, [2], and the geomorphologic equation, [3], are both expressed as functions of $b$, so they can be equated to become:

$Q_{100} n s^{-0.5} d_{h}^{-1.667}=43.7 Q_{m}^{0.38} M^{-0.34}$

Equation [4] and equation [5] can be combined to obtain: 
$d_{h}^{-1.667}=43.7\left(Q_{m} / Q_{100}\right) Q_{m}^{-0.62} n^{-1} s^{0.5} M^{-0.39}$

Then equation [6] can be reformulated to obtain the hydraulic depth:

$d_{h}=(43.7)^{-0.6}\left(Q_{m} / Q_{100}\right)^{-0.6} Q_{m}^{0.372} n^{0.6} s^{-0.3} M^{0.234}$

The channel profile slope, $s$, and the percentage of silt and clay, $M$, are physical properties that can be measured at a watershed. The Strickler relation (Anderson, et al, 1970) can be used to estimate the Manning's roughness coefficient, $n$, with the following equation:

$n=0.0488\left(D_{50} / 1000\right)^{0.167}$

where: $D_{50} \quad$ is the median size of the rock riprap (mm).

The value of $D_{50}$ can be estimated from a preliminary analysis, and this value can then be used to compute an interim $D_{50}$ for the erosion protection. The final value of $D_{50}$ can be obtained with an iterative process. Including equation [8] in equation [7] results in:

$d_{h}=(43.7)^{-0.6}\left(\frac{Q_{m}}{Q_{100}}\right)^{-0.6} Q_{m}^{0.372}\left[0.0488\left(\frac{D_{50}}{1000}\right)^{0.167}\right]^{0.6} s^{-0.3} M^{0.234}$

Equations [3] and [9] describe the flow width and depth based on the geomorphologic equation of Simons, $\mathrm{Li}$ and Associates. Except for the $D_{50}$, all of the values in these equations can be estimated from physical watershed properties. The equations can also be used to compute the 100-year event unit discharge, $Q_{100} / \mathrm{b}$, and the width-to-depth ratio, $b / d_{h}$. While the dominant discharge, $Q_{m}$, is used in equation [9], the computed hydraulic depth, $d_{h}$, represents the depth from a 100-year frequency event.

A second geomorphologic parameter is the width-to-depth ratio of the flowing water. For arid and semi-arid locations the maximum width-to-depth ratio is approximately 40 , although other values may need to be considered for local conditions. If the width-to-depth ratio, $b / d_{h}$, using equations [3] and [9] exceeds 40 , the $b$ and the $d_{h}$ should to be re-computed to maintain a width-to-depth ratio of 40 . The width-to-depth relation can be represented with the following equation:

$b=F d_{h}$

where: $F \quad$ is the width-to-depth ratio. (Commonly a value of 40)

Equation [2] and equation [10] can be combined to obtain: 
$Q_{100} n s^{-0.5} d_{h}^{-1.667}=F d_{h}$

This equation can be reformulated to compute the hydraulic depth as:

$d_{h}=\left[\left(Q_{100} n\right) / F\right]^{0.375} s^{-0.1875}$

Equations [10] and [12] describe the flow width and depth based on a defined width-to-depth ratio. Equations [10] and [12] should be used whenever the $b / d_{h}$ computed from equations [3] and [9] exceeds 40. Using equations [3] and [9], or equations [10] and [12], the flow velocity, $V_{100}$, the Froude number, $F_{r}$, the width of flow, $b$, and the unit discharge, $q_{f}$, can be computed.

\section{ROCK SIZES AND ADMIXTURE LAYER THICKNESS}

With the flow properties established, the S. R. Abt and T. L. Johnson equation (1991) can be used to solve for the median rock size of the gravel veneer. A factor of safety of 1.2 should be applied to the rock size equation as recommended on page 967 of the Abt and Johnson paper. The Abt and Johnson equation uses the unit discharge, and profile slope to compute the median rock size when failure is expected to occur. The unit discharge is computed using the smallest $b$ obtained from equation [3] and equation [10] so that the computed unit discharge is the maximum value computed from the two equations. The equation for unit discharge is:

$q_{f}=Q_{100} / b$

where: $q_{f} \quad$ is the unit discharge or unit flow rate $\left(\mathrm{m}^{2} / \mathrm{s}\right)$.

The Abt and Johnson equation with the addition of the recommended factor of safety and converted to metric form is:

$D_{50}=(12 \times 502.9) s^{0.43} q_{f}^{0.56}$

where: $D_{50} \quad$ is the median rock size of the gravel veneer.

The physical testing by Abt and Johnson did not use slopes steeper than $20 \%$ $(0.20 \mathrm{~m} / \mathrm{m})$. Abt and Johnson's paper suggested that the gravel layer thickness should be 1.5 to 3.0 times the $D_{50}$. The $D_{50}$ computed from equation [14] can be used to determine the rock gradation for the gravel portion of the gravel admixture layer. The following procedure is recommended:

- $\quad$ specify a construction minimum $D_{50}\left(D_{50-m i n}\right)$ based on the computed value from equation [14] rounded to the nearest $6.4 \mathrm{~mm}$ (0.25 inch).

- $\quad$ specify a design maximum $D_{50}\left(D_{50-\max }\right)$ at $140 \%$ of the $D_{50-\min }$, rounded to the nearest $6.4 \mathrm{~mm}(0.25 \mathrm{inch})$.

- specify a minimum $D_{100}\left(D_{100-\min }\right)$ at $150 \%$ of the $D_{50-\min }$, rounded to the nearest $6.4 \mathrm{~mm}$ (0.25 inch). 
- $\quad$ specify a design maximum $D_{100}\left(D_{100-\max }\right)$ at $200 \%$ of the $D_{50-\min }$, rounded to the nearest $6.4 \mathrm{~mm}(0.25 \mathrm{inch})$. The constructed admixture can have a larger value with an appropriate adjustment in the layer thickness.

- $\quad$ specify a minimum $D_{15}\left(D_{15-\min }\right)$ at $45 \%$ of the $D_{50-\min }$, rounded to the nearest $6.4 \mathrm{~mm}(0.25 \mathrm{inch})$.

- $\quad$ specify a design maximum $D_{15}\left(D_{15-\max }\right)$ at $80 \%$ of the $D_{50-m i n}$, rounded to the nearest $6.4 \mathrm{~mm}(0.25 \mathrm{inch})$.

- $\quad$ specify the coefficient of uniformity $\left(C_{u}=D_{60} / D_{10}\right)$ with an allowable range between 1.75 and 3.0 .

The Abt and Johnson physical testing used rock with an average specific gravity of 2.66. In order to use this equation without adjustment, the rock in the gravel admixture should have an average specific gravity of 2.65 or larger. This is equivalent to a particle unit weight of $2650 \mathrm{~kg} / \mathrm{m}^{3}\left(165 \mathrm{lbs} / \mathrm{ft}^{3}\right)$. If any rock with a smaller average specific gravity is proposed for use, the size of the $D_{15}, D_{50}, D_{100}$, and $Y_{\min }$ would need to be adjusted based on the ratio of the buoyant weight of the rock.

The gravel admixture should have a constructed percentage of gravel of not less than $25 \%$ and not more than $50 \%$ of the total admixture. To maintain these limits it is recommended that the design percentage of gravel be established between 30 and $45 \%$. The total thickness of the gravel admixture layer is the sum of the minimum rock layer thickness plus the scour depth. The total admixture layer thickness is computed as follows:

- $\quad$ specify the minimum rock layer thickness $\left(Y_{\text {min-rock }}\right)$ at the 2.0 times the $D_{50-m i n}$, or 1.0 times the $D_{100-m a x}$, whichever is larger.

- $\quad$ compute the scour depth $\left(Y_{s}\right)$ with the equation:

$$
Y_{s}=Y_{\min -\operatorname{rock}}[(100 / \% \text { Gravel })-1.25]
$$

- compute the total admixture layer thickness $\left(Y_{\text {total }}\right)$ as:

$$
Y_{\text {total }}=Y_{s}+\left(1.5 \times Y_{\min -\text { rock }}\right)
$$

with $Y_{\text {total }}$ rounded to the nearest $0.025 \mathrm{~m}$ (1.0 inch). The minumum recommended value of $Y_{\text {total }}$ is $0.15 \mathrm{~m}$ ( 6 inches) for slopes between 0 and $10 \%$. The minimum recommended value of $Y_{\text {total }}$ is $0.30 \mathrm{~m} \mathrm{(12}$ inches) for slopes greater than $10 \%$.

\section{\% OF GRAVEL, "FINER SOIL" AND "GENERAL SOIL"}

In order for the gravel admixture layer to retain its properties of reduced surface infiltration and increased evaporation, constraints must be placed on the quantity of gravel in the admixture layer and on the remaining soil that is smaller than gravel. The percentage of gravel in an admixture layer is computed by comparing the computed $D_{50-\min }$ and $D_{15-\min }$ with the percentages in the proposed gradation that are at these computed sizes. For example, if a specified admixture has a higher percentage of 
particles larger than the computed $D_{50-\min }$, the percentage of gravel in the admixture gradation is larger than with an optimal gradation. The percentage of gravel in a gravel admixture is estimated by first computing the percent of the mix that passes the computed $D_{50-\min }$ and the computed $D_{15-\min }$ to obtain the $\%$ Passing $D_{50}$ and $\%$ Passing $D_{15}$ in the proposed mix. These values are then used to estimate the percentage of gravel in the mix using the following equation:

$\%$ Gravel $=\left[1.24 \times\left(1-\%\right.\right.$ Passing $\left.\left.D_{50}\right)\right]+\left[0.36 \times\left(1-\%\right.\right.$ Passing $\left.\left.D_{15}\right)\right]$

The equivalent particle size for the gravel can be found by computing the gradation particle size that corresponds to the \% Gravel. The range of $\%$ Gravel in the admixture should be between $5 \%$ and $50 \%$. For the soil material in the admixture that is smaller than gravel, the gradation is further described as "finer soil" and "general soil". Finer soil is all soil material smaller than a \#4 sieve $(4.75 \mathrm{~mm})$. In order to maintain good infiltration resistance and evaporation rates, the percentage of finer soil in the admixture should not be less than $34 \%$. The finer soil should also have a minimum percentage of silt or clay size particles (particles passing a \#200 sieve, or smaller than $0.075 \mathrm{~mm}$ ) with the silt and clay at $5 \%$ to $50 \%$ by weight of the finer soils. A large percentage of clay size particles (smaller than $0.005 \mathrm{~mm}$ ) in the finer soils could cause surface cracking, and it is suggested that clay size particles should not exceed $40 \%$ by weight of the finer soils. Additional specifications to limit the content of expansive clay and dispersive clays are recommended. For the gravel admixture, the finer soils should be between $34 \%$ and $95 \%$ by weight of the admixture. The soils that are finer than the gravel and larger than the $\# 4$ sieve $(4.75 \mathrm{~mm})$ are considered to be general soils. General soils are not required for the gravel admixture but they are expected to be present in a normal admixture gradation. General soils can be $0 \%$ to $60 \%$ by weight of the total gravel admixture.

In order for the gravel admixture to function as an erosion barrier, there must be a sufficient quantity of gravel in the admixture layer so the admixture layer can protect the soil layers below the admixture layer. The thickness of the gravel portion required to provide erosion protection for the admixture layer is approximately 3 times the computed $D_{50-\min }$. This ratio of the rock layer thickness to $D_{50-\min }$ is greater than commonly used for larger riprap, because of the smaller size material and the reduced precision of individual particle placement. Ratios of 3 to 4 are commonly recommended for finer rock sizes. If the percentage of gravel in the admixture is $80 \%$ by weight, the finer material would have a volume nearly equal to the void space between the stable gravel particles, and there would be no need for consideration of additional layer thickness. However, the percentage of gravel in the admixture will be between $5 \%$ and $50 \%$, so that a major portion of the required admixture thickness is due the material smaller than gravel. Additional layer thickness is required because the particles smaller than the gravel will be removed by channelized erosive flows. At $45 \%$ gravel the total admixture thickness will need to be approximately 5 times the computed $D_{50-\min }$, and at $21 \%$ gravel the total admixture thickness will need to be approximately 10 times the computed $D_{50-m i n}$.

When a single proposed material gradation is evaluated as a gravel admixture layer, the gradation sizes are compared with the computed $D_{50-\min }$ and $D_{15-\min }$ to 
determine the $\%$ Gravel. Then the percentages of the finer soil and the general soil are determined. These values are compared with the allowable percentages for each material classification. Finally the thickness of the total admixture layer is established.

\section{GRAVEL ADMIXTURE SELECTION FOR A GRADATION RANGE}

The procedure for the gravel admixture can be used to test for a single specified gradation and determine the applicable layer thickness appropriate to that gradation. It does not directly give the appropriate thickness when a gradation range is specified for a given location. When a gradation range is identified, the material that could be supplied may fall anywhere within the gradation band. Checking the computed thickness for only the minimum and maximum gradations does not provide a thorough examination of the possible gradations. A series of nine possible gradation scenarios within the specified gradation range is examined to determine the critical admixture layer thickness, $Y_{\text {Total }}$, applicable to a single slope and length condition. While each of the gradation scenarios will be within the specified gradation range, computations commonly show that the maximum layer thickness is obtained when using a gradation other than the maximum or minimum gradation. A single thickness and slope is used to compute the $Y_{\text {Total }}$ for a specified gradation, but it is also possible to examine a range of slopes and lengths from $3 \%$ to $10 \%$ that can utilize the same gradation and $Y_{\text {Total }}$.

\section{APPLICATION OF DESIGN PARAMETERS}

A gravel admixture was applied to a typical municipal landfill site in a semi-arid climate. A multiple page spreadsheet was used to perform the computation. A section of a top cover with an area of $0.173 \mathrm{ha}(0.428 \mathrm{ac})$ and a uniform slope of 0.05 $\mathrm{m} / \mathrm{m}$ is considered. A summary of the design parameters are given below:

Design storm for erosion stability $=100$-year frequency $(1 \%$ per year $)$

Top slope $=0.05 \mathrm{~m} / \mathrm{m}(5 \%)$

Overland flow slope length $=83 \mathrm{~m}(273 \mathrm{ft})$

Peak flow $=0.071 \mathrm{~m}^{3} / \mathrm{s}(2.5 \mathrm{cfs})$

Unit flow rate $=0.042 \mathrm{~m}^{2} / \mathrm{s}\left(0.454 \mathrm{ft}^{2} / \mathrm{s}\right)$

Maximum channel velocity $=1.006 \mathrm{~m} / \mathrm{s}(3.30 \mathrm{ft} / \mathrm{s})$

Hydraulic depth of channel flow $=42 \mathrm{~mm}(0.138 \mathrm{ft})$

Froude number $=1.57$

Computed $D_{50}$ of gravel portion $=28 \mathrm{~mm}$ (1.11 in.), use $32 \mathrm{~mm}$ (1.25 in.)

Required thickness of armor layer $=57 \mathrm{~mm}(2.25 \mathrm{in}$.)

Computed thickness of gravel/soil admixture layer, $Y_{\text {Total }}=0.254 \mathrm{~m}(10 \mathrm{in}$.)

The design admixture gradation for the 0.173 ha area at a slope of $0.05 \mathrm{~m} / \mathrm{m}$ is shown on Figure 1. The design admixture gradation from Figure 1 with a layer thickness, $Y_{\text {Total }}$, of $0.254 \mathrm{~m}$ (10 in) and slope of $0.05 \mathrm{~m} / \mathrm{m}(5 \%)$ can also be applied to a spreadsheet analysis for slopes from 0.03 to $0.10 \mathrm{~m} / \mathrm{m}$ (3 to $10 \%$ ). Slopes flatter than $0.05 \mathrm{~m} / \mathrm{m}$ will allow larger runoff areas and longer overland flow slope lengths, and slopes steeper than $0.05 \mathrm{~m} / \mathrm{m}$ will require smaller runoff areas and shorter overland flow slope lengths. 


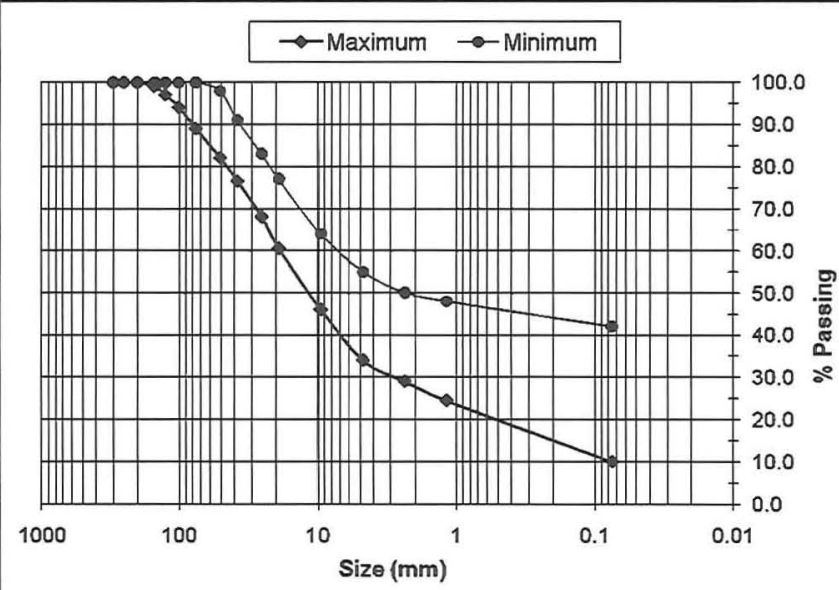

Figure 1. Admixiure Gradation for 0.173 ha @ $5.0 \%$

Table 1 shows values for the runoff areas and overland flow lengths that can be applied to the Figure 1 gradation with a $0.254 \mathrm{~m}$ (10 in) layer thickness. Moderate increases in the allowable runoff areas and overland flow lengths can also be obtained by increasing the layer thickness to $0.305 \mathrm{~m}$ (12 in) for the same gradation range. Table 1 also shows the areas and overland flow length when the thickness is increased.

Table 1. Gravel Admixture Runoff Areas and Overland Flow Lengths

\begin{tabular}{|c|c|c|c|c|c|c|c|c|}
\hline $\begin{array}{c}\text { Layer } \\
\text { thickness } \\
(\mathrm{m}) \\
\end{array}$ & $\begin{array}{c}\text { Max. } \\
\text { Area at } \\
3 \% \\
\text { slope } \\
\text { (ha) }\end{array}$ & $\begin{array}{c}\text { Max. } \\
\text { Area at } \\
4 \% \\
\text { slope } \\
\text { (ha) }\end{array}$ & $\begin{array}{c}\text { Max. } \\
\text { Area at } \\
5 \% \\
\text { slope } \\
\text { (ha) }\end{array}$ & $\begin{array}{c}\text { Max. } \\
\text { Area at } \\
6 \% \\
\text { slope } \\
\text { (ha) }\end{array}$ & $\begin{array}{c}\text { Max. } \\
\text { Area at } \\
7 \% \\
\text { slope } \\
\text { (ha) }\end{array}$ & $\begin{array}{c}\text { Max. } \\
\text { Area at } \\
8 \% \\
\text { slope } \\
\text { (ha) }\end{array}$ & $\begin{array}{c}\text { Max. } \\
\text { Area at } \\
9 \% \\
\text { slope } \\
\text { (ha) }\end{array}$ & $\begin{array}{l}\text { Max. } \\
\text { Area at } \\
10 \% \\
\text { slope } \\
\text { (ha) }\end{array}$ \\
\hline 0.254 & 0.372 & 0.244 & 73 & 0 & 0. & 0.084 & 0.070 & 0.060 \\
\hline 0.305 & 0.590 & 0.379 & 0.270 & 0.203 & 0.161 & 0.132 & 0.109 & 0.093 \\
\hline $\begin{array}{c}\text { Layer } \\
\text { thickness } \\
(\mathrm{m})\end{array}$ & $\begin{array}{l}\text { Max. } \\
\text { Length } \\
\text { at 3\% } \\
\text { slope } \\
\text { (m) }\end{array}$ & $\begin{array}{c}\text { Max. } \\
\text { Length } \\
\text { at } 4 \% \\
\text { slope } \\
\text { (m) }\end{array}$ & $\begin{array}{c}\text { Max. } \\
\text { Length } \\
\text { at } 5 \% \\
\text { slope } \\
(\mathrm{m})\end{array}$ & $\begin{array}{c}\text { Max. } \\
\text { Length } \\
\text { at 6\% } \\
\text { slope } \\
\text { (m) }\end{array}$ & $\begin{array}{l}\text { Max. } \\
\text { Length } \\
\text { at 7\% } \\
\text { slope } \\
\text { (m) }\end{array}$ & $\begin{array}{l}\text { Max. } \\
\text { Length } \\
\text { at } 8 \% \\
\text { slope } \\
\text { (m) }\end{array}$ & $\begin{array}{c}\text { Max. } \\
\text { Length } \\
\text { at 9\% } \\
\text { slope } \\
\text { (m) }\end{array}$ & $\begin{array}{l}\text { Max. } \\
\text { Length } \\
\text { at } 10 \% \\
\text { slope } \\
\text { (m) }\end{array}$ \\
\hline 0.254 & 122 & 99 & 83 & 72 & 64 & 58 & 53 & 49 \\
\hline 0.305 & 154 & 123 & 104 & 90 & 80 & 73 & 66 & 61 \\
\hline
\end{tabular}

A similar gravel admixture design was applied to a demonstration landfill cover constructed in northwestern New Mexico (Anderson and Stormont, 2005). The procedure described here is being applied to a landfill cover soon to be constructed in 
southern Nevada. The Nevada project will provide the first large scale application of the procedure.

\section{CONCLUSIONS}

Measures to control erosion are a significant part of the safe function of landfills. While measures such as revegetation and application of organic mulches may reduce erosion in some climates, mechanical stabilization by a gravel veneer or a gravel admixture layer will likely be required to prevent water erosion in the arid and semi-arid Southwest. The design method for gravel admixtures presented here may provide erosion protection that does not reduce the evaporation rate, or create a habitat for deep-rooted plants.

\section{REFERENCES}

Abt, S. R. and Johnson, T. L. (1991). "Riprap Design for Overtopping Flow.” Journal of Hydraulic Engineering, 117 (8), pp 959-972.

Anderson, C. E., and Stormont, J. C. (2005). "Gravel Advixtures for Erosion Protection in Semi-Arid Climates." Erosion of Soils and Scour of Foundations, Proceedings of Sessions of the Geo-Frontiers 2005 Congress, Austin, Texas.

Anderson, G. K, et al, (1970). Tentative Design Procedure for Riprap-Lined Channels, Highway Research Board, NCHRP Report Number 108.

Finley, J. B., Harvey, M. D., and Watson, C. C. (1985). "Experimental Study: Erosion of Overburden Cap Material Protected by Rock Mulch." Seventh Symposium on Management of Uranium Mill Tailings, Low-Level Waste and Hazardous Waste, Fort Collins, Colorado, 273-282.

Kemper, W. D., Nicks, A. D., and Corey, A. T. (1994). "Accumulation of Water in Soils under Gravel and Sand Mulches." Soil Science Society of America Journal, 58, 56-63.

Simons, D. B., Li, R. M., et al. (1980). Watershed and Stream Mechanics, prepared for the US Department of Agriculture, Soil Conservation Service, Washington, D.C.

Simons, Li and Associates (1982). Engineering Analysis of Fluvial Systems, Fort Collins, CO.

Waugh, W. J., and Petersen, K. L. (1994). "Paleoclimatic Data Application: Long-term Performance of Uranium Mill Tailings Repositories." Climate Change in the Four Corners and Adjacent Regions: Implications for Environmental Restoration and Land-Use Planning, Proceedings of the Workshop, Mesa State College, Grand Junction, Colorado, 163-185.

Wischmeier, W. H., and Smith, D. D. (1978). "Predicting Rainfall Erosion Losses, A Guide to Conservation Planning." Agriculture Handbook Number 537, United States Department of Agriculture, Science and Education Administration, Washington, D.C. 